\title{
Propofol infusion syndrome: early blood purification to the rescue?
}

\author{
Patrick M. Honore ${ }^{*}$ and Herbert D. Spapen \\ See related research by Krajčová et al., http://ccforum.biomedcentral.com/articles/10.1186/s13054-015-1112-5
}

We read with interest the comprehensive review of Krajčová et al. [1] on propofol infusion syndrome (PRIS). Of particular importance is the high (51 \%!) associated mortality which is mainly determined by cardiac failure, therapy-resistant bradyarrhythmia, metabolic acidosis, and rhabdomyolysis [1]. The authors provide a detailed insight on the pathophysiologic mechanism(s) underlying PRIS but do not discuss therapy, probably because therapeutic options are limited and merely supportive. Basically, propofol should be withdrawn immediately and adequate hemodynamic support must be ensured. Patients who develop rhabdomyolysis-associated acute kidney injury (AKI) are treated with hemodialysis or hemofiltration. Extracorporeal membrane oxygenation was life-saving in two patients [2]. A recent case report described rapid hemodynamic improvement and resolution of lactic acidosis after one single session of plasma exchange [3].

We suggest that early initiation of continuous renal replacement therapy (CRRT), even in the absence of well-established indications such as AKI, metabolic acidosis, or hyperkalemia, might add a survival benefit. Propofol undergoes hepatic metabolization and is rapidly cleared by the kidneys as propofol-glucuronide and 2,6-diisopropyl1,4-quinol sulfo- and glucuro-conjugates [4]. Unlike the highly lipophilic parent drug, these toxic water-soluble metabolites can be eliminated by CRRT. Caution is needed, however, when implementing such a strategy. Prolonged PRIS-related cardiogenic shock with severely compromised hepatic and muscle perfusion may dramatically reduce mitochondrial citrate metabolism and result in citrate accumulation. As citrate is increasingly used for regional anticoagulation during CRRT, tight monitoring of the ionized/ total calcium ratio is imperative to obviate metabolic complications related to citrate intoxication. A ratio exceeding

* Correspondence: Patrick.Honore@az.vub.ac.be

ICU Department, Universitair Ziekenhuis Brussel, Vrije Universiteit Brussel, 101, Laarbeeklaan, 1090, Jette, Brussels, Belgium
2.25 strongly suggests citrate overdose and requires replacing citrate by unfractionated heparin [5].

\section{Abbreviations \\ AKI, acute kidney injury; CRRT, continuous renal replacement therapy; PRIS, propofol infusion syndrome}

\section{Authors' contributions}

$\mathrm{PMH}$ and HDS designed the paper, participated in drafting the manuscript, and have read and approved the final version.

\section{Competing interests}

The authors declare that they have no competing interests.

Received: 22 April 2016 Accepted: 31 May 2016

Published online: 04 July 2016

\section{References}

1. Krajčová A, Waldauf $P$, Anděl $M$, Duška F. Propofol infusion syndrome: a structured review of experimental studies and 153 published case reports. Crit Care. 2015;19:398.

2. Fudickar A, Bein B. Propofol infusion syndrome: update of clinical manifestation and pathophysiology. Minerva Anestesiol. 2009;75:339-44.

3. Levin PD, Levin V, Weissman C, Sprung CL, Rund D. Therapeutic plasma exchange as treatment for propofol infusion syndrome. J Clin Apher. 2015; 30:311-3.

4. Favetta P, Degoute CS, Perdrix JP, Dufresne C, Boulieu R, Guitton J. Propofol metabolites in man following propofol induction and maintenance. $\mathrm{Br} J$ Anaesth. 2002:88:653-8.

5. Oudemans-van Straaten HM, Ostermann M. Bench-to-bedside review: Citrate for continuous renal replacement therapy, from science to practice. Crit Care. 2012;16:249.

Submit your next manuscript to BioMed Central and we will help you at every step:

- We accept pre-submission inquiries

- Our selector tool helps you to find the most relevant journal

- We provide round the clock customer support

- Convenient online submission

- Thorough peer review

- Inclusion in PubMed and all major indexing services

- Maximum visibility for your research

Submit your manuscript at www.biomedcentral.com/submit
C Biomed Central 